\title{
Retinoblastoma Heritable Trait (H) Finding v8
}

National Cancer Institute

\section{Source}

National Cancer Institute. Retinoblastoma Heritable Trait (H) Finding v8. NCI Thesaurus. Code C140726.

A finding about a heritable trait of retinoblastoma, following the rules of the AJCC v8 classification system. 